\title{
NADPLATA PODATKU POWSTAŁA W WYNIKU ORZECZENIA TRYBUNAŁU KONSTYTUCYJNEGO
}

Ostatnio w orzecznictwie sądów administracyjnych często rozważa się skutki wyroków Trybunału Konstytucyjnego o niezgodności zaskarżonego przepisu ustawy podatkowej z Konstytucją. Doniosłe konsekwencje finansowe wynikające $\mathrm{z}$ takich wyroków dla Skarbu Państwa, a więc dla całego społeczeństwa, oraz kwestie tytułów prawnych podmiotów uprawnionych do skorzystania z sytuacji ukształtowanej stwierdzeniem niekonstytucyjności stały się przedmiotem analiz sądów w konkretnych sprawach. Problemy, jakie rodzą się na tym tle, wynikaja z braku określenia istoty i charakteru pojęcia ,nadpłata powstała w wyniku orzeczenia Trybunału Konstytucyjnego" ${ }^{1}$. Konieczna wydaje się zatem próba zdefiniowania roszczenia z art. 74 Ordynacji podatkowej, w szczególności w relacji do art. 190 ust. 4 Konstytucji $\mathrm{RP}^{2}$, określającego skutki wyroków Trybunału Konstytucyjnego.

Choć pojęcie ,nadpłata powstała w wyniku orzeczenia Trybunału Konstytucyjnego" zostało wprowadzone już do pierwotnego tekstu Ordynacji podatkowej z 1997 r., nie było ono do tej pory przedmiotem pogłębionej analizy, mającej na celu zbadanie, czym z natury swej jest ta ,nadpłata”. Obecnie dyskusja skupia się przede wszystkim na tytułach prawnych podmiotów uprawnionych do żądania jej zwrotu, a w szczególności na kwestii, czy zubożenie podatnika jest przesłanką roszczenia o zwrot „,nadpłaty” ${ }^{3}$. Problematyka ta nie jest objęta zakresem tego artykułu.

\section{UREGULOWANIA ART. 74 O.P. W KONTEKŚCIE NADPŁATY OKREŚLONEJ W ART. 72 O.P.}

O tym, że podatek zapłacony na podstawie przepisu uznanego za niezgodny z Konstytucją podlega zwrotowi, przesądza art. 74 o.p. Ustawodawca, wskazując, że przepis ten dotyczy nadpłat w podatkach, w których zobowiązania powstaja $\mathrm{z}$ mocy prawa, określił jednocześnie jego zakres podmiotowy i przedmiotowy. Uprawnionymi do żądania zwrotu nadpłaty są podatnicy,

\footnotetext{
1 Pojęcie „nadpłata” zostało użyte w cudzysłowie w celu zaznaczenia różnicy, co do jej natury prawnej, względem nadpłaty z art. 72 Ordynacji podatkowej. Ustawa z 29 sierpnia 1997 r. - Ordynacja podatkowa, tekst pierwotny: Dz. U. Nr 137, poz. 926 (dalej jako: o.p.).

${ }^{2}$ Ustawa z 2 kwietnia 1997 r. Konstytucja Rzeczypospolitej Polskiej, Dz. U. Nr 78, poz. 48 ze zm.

${ }^{3}$ Zob. np. uchwała NSA z 13 lipca 2009 r., I FPS 4/09 oraz z 22 czerwca 2011 r., I GPS 1/11.
} 
których zobowiązania podatkowe powstają w sposób przewidziany w art. $21 \S 1$ pkt 1 o.p., niezależnie od tego, czy do obliczenia i zapłaty podatku zobowiązany jest podatnik, czy płatnik.

$\mathrm{Z}$ art. 74 o.p. wynika również, że ,nadpłata powstała w wyniku orzeczenia TK" zwracana jest tylko na wniosek, któremu towarzyszyć musi skorygowana deklaracja lub zeznanie podatkowe. Podatnik we wniosku obowiązany jest sam określić wysokość nadpłaty. Obowiązek złożenia skorygowanej deklaracji lub zeznania nie dotyczy oczywiście podatników tych podatków, w których nie jest wymagane ujawnienie zobowiązania podatkowego $\mathrm{w}$ deklaracji lub zeznaniu podatkowym.

Artykuł 74 o.p. nie zawiera jednak definicji pojęcia „nadpłata powstała w wyniku orzeczenia TK". Konstrukcja tej regulacji nie jest oparta na kryteriach materialnych, które pozwalałyby na ustalenie jej natury prawnej. Kryteriów takich nie określa także art. 72 o.p. Dlatego też nie można w sposób jednoznaczny ustalić: 1) czy „nadpłata” $\mathrm{z}$ art. 74 o.p. mieści się w zakresie użytych w art. $72 \S 1$ pkt 1 o.p. pojęć ,,podatek nadpłacony” lub „,podatek nienależnie zapłacony"; 2) czy powinna być wymieniona jako jeden z pozostałych wypadków świadczeń uiszczonych bez podstawy prawnej, które ustawodawca za nadpłatę uważa, określonych w katalogu art. 72 o.p.; 3) czy „nadpłata” ta wymaga odrębnej regulacji i nie należy jej utożsamiać ani z nadpłata, o której mowa w art. $72 \S 1$ pkt 1 o.p., ani ze świadczeniami określonymi w innych przepisach tego artykułu, gdyż ustawodawca w sposób celowy uregulował ją odrębnie.

Posłużenie się przez ustawodawcę w art. 74 o.p. zwrotem „,nadpłata” może sugerować, że albo mieści się ona w zakresie art. $72 \S 1$ pkt 1 o.p., albo powinna zostać ujęta jako jedno ze świadczeń wymienionych w przepisach art. 72 o.p. Wątpliwości te -jak się wydaje - wynikają nie tylko z braku klasycznej definicji nadpłaty, lecz także $\mathrm{z}$ wadliwej konstrukcji art. 72 o.p. W literaturze przedmiotu wielokrotnie podkreślano, że wbrew literalnemu brzmieniu art. 72 o.p. przepis ten nie określa zamkniętego katalogu wypadków powstawania nadpłat. Wskazuje się, że także w innych przepisach rozdziału 9 Ordynacji podatkowej określone zostały nadpłaty podlegające zwrotowi na podstawie jej przepisów ${ }^{4}$.

W orzecznictwie sądów ,nadpłata powstała w wyniku orzeczenia TK” traktowana jest jako świadczenie pobrane bez podstawy prawnej i kwalifikowana jako mieszcząca się $\mathrm{w}$ zakresie art. $72 \S 1$ pkt 1 o.p. ${ }^{5}$ Pogląd taki wyrażany jest także $\mathrm{w}$ doktrynie - podkreśla ona, że art. 74 o.p. określa jedynie inny sposób powstania nadpłaty, o której mowa w art. $72 \S 1$ o.p. ${ }^{6}$, lub też odrębny tryb jej zwrotu ${ }^{7}$. Jednakże niektóre sądy, zauważając istotne różnice związane ze stanem faktycznym powstania tej „,nadpłaty”, wskazują, że nie

${ }^{4}$ Por. np. B. Gruszczyński, w: S. Babiarz et al., Ordynacja podatkowa. Komentarz, Warszawa 2011, s. 423.

${ }^{5}$ Zob. np.: wyrok NSA w Warszawie z 9 maja 2006 r., I FSK 1034/05, Lex, nr 282615.

${ }^{6}$ Zob. K. Lasiński-Sulecki, W. Morawski, Zwrot nadptaty podatku konsumpcyjnego pobranego niezgodnie $z$ prawem wspólnotowym $w$ orzecznictwie sadów polskich $i$ Europejskiego Trybunatu Sprawiedliwości, „Przegląd Orzecznictwa Podatkowego” 2009, nr 3, s. 200.

${ }^{7}$ B. Gruszczyński, w: S. Babiarz et al., op. cit., s. 431. 
chodzi tu o wadliwe, lecz o prawidłowe stosowanie obowiązującego przepisu prawa, który następnie został uznany za niezgodny z aktem wyższego rzędu. Konsekwencją tego jest jakościowa różnica stanu faktycznego, pociągająca za sobą odrębne uregulowanie tej „,nadpłaty”.

Jeżeli chodzi o sposób powstania „nadpłaty” w wyniku wyroku TK i tryb jej zwrotu, to niewątpliwie należy zgodzić się ze wspomnianym powyżej poglądem. Nie ulega wątpliwości, że sposób jej powstania, wywołany przez, nieporównywalny z nadpłatą, o której mowa w art. 72 o.p., stan faktyczny, warunkuje konieczność dostosowania regulacji związanej z trybem jej dochodzenia do skutków wyroków Trybunału Konstytucyjnego. Warunkiem powstania uprawnienia do zwrotu jest wyrok Trybunału stwierdzający niekonstytucyjność przepisu będącego podstawą zapłaty podatku ${ }^{9}$.

Zauważyć jednak należy, że z treści art. 74 o.p. można wnioskować nie tylko o sposobie powstania „nadpłaty”, podmiotach uprawnionych do wystapienia z roszczeniem o jej zwrot, rodzajach podatków, w których roszczenie takie przysługuje i trybie dochodzenia, lecz także można dekodować treść pojęcia „,nadpłata powstała w wyniku orzeczenia Trybunału Konstytucyjnego”. Wnioskowanie o istocie i charakterze tej „nadpłaty” nie jest wprawdzie możliwe na podstawie samoistnej interpretacji art. 74 o.p. jedynie na podstawie jego brzmienia, ale uwzględnienie kryteriów konstytucyjnych pozwala na określenie jej cech istotnych.

Ponieważ chodzi tu o „nadpłatę powstała w wyniku orzeczenia TK”, a warunkiem jej powstania jest wyrok Trybunału stwierdzajacy niekonstytucyjność przepisu będącego podstawą zapłaty podatku, za kryteria takie należy przyjąc te przepisy Konstytucji, które kształtuja skutki wyroków Trybunału. Dopiero ich uwzględnienie pozwala na dokonanie rekonstrukcji treści normatywnej art. 74 o.p. w zakresie użytego w nim pojęcia „,nadpłata powstała w wyniku orzeczenia Trybunału Konstytucyjnego". Natomiast pominięcie znaczenia przepisów konstytucyjnych przy analizie „,nadpłaty” z art. 74 o.p. i konsekwencji, jakie wynikają z przyjętego przez ustrojodawcę modelu skutków wyroków TK, nie daje pełnego jej obrazu i prowadzi do błędnych wniosków.

Przepisem, regulującym skutki wyroków TK, który należy uwzględnić badając treść art. 74 o.p., jest art. 190 ust. 1, 3 i 4 Konstytucji RP.

\section{SKUTKI WYROKÓW TRYBUNAŁU KONSTYTUCYJNEGO}

Zgodnie z art. 190 ust. 1 Konstytucji ,orzeczenia Trybunału Konstytucyjnego mają moc powszechnie obowiązująca i są ostateczne”. Wchodzą one w życie z dniem ogłoszenia, jednak Trybunał Konstytucyjny może określić inny termin utraty mocy obowiązującej aktu normatywnego (art. 190 ust. 3 Konstytucji RP). Termin ten nie może przekroczyć osiemnastu miesięcy, gdy chodzi o ustawę, i dwunastu miesięcy w wypadku innych aktów normatywnych.

${ }^{8}$ Por. wyrok WSA w Gdańsku z 25 lutego 2010 r., I SA/Gd 880/09, Lex nr 599452.

${ }^{9}$ Zob. wyrok NSA w Warszawie z 9 maja 2006 r., I FSK 1034/05, Lex, nr 282615. 
W świetle natomiast art. 190 ust. 4 Konstytucji RP, orzeczenie TK o niezgodności z Konstytucją, umową międzynarodową lub z ustawą aktu normatywnego, na podstawie którego zostało wydane prawomocne orzeczenie sądowe, ostateczna decyzja administracyjna lub rozstrzygnięcie w innych sprawach, stanowi podstawę do wznowienia postępowania, uchylenia decyzji lub innego rozstrzygnięcia na zasadach i w trybie określonych w przepisach właściwych dla danego postępowania.

Jak wynika z art. 190 ust. 1 Konstytucji RP, ustrojodawca nadał wyrokom TK moc powszechnie obowiązująca oraz przymiot ostateczności. Natomiast wybierając model kształtowania skutków wyroków Trybunału Konstytucyjnego w art. 190 ust. 3 Konstytucji RP, polski ustrojodawca oparł się na teorii wzruszalności (vernichtsbarkeitslehre) przyjętej w prawie austriackim na bazie „,czystej doktryny prawa” Kelsena ${ }^{10}$. Zgodnie z tą teoria wyrok sądu konstytucyjnego ma charakter konstytutywny ze skutkiem na przyszłość. Oznacza to, że do czasu wydania wyroku sądu konstytucyjnego przepis, choć niezgodny z konstytucją, jest przepisem obowiązującym w systemie prawa i wywołuje skutki prawne. Dopiero stwierdzenie niekonstytucyjności powoduje jego derogację. Nie usuwa jednak wadliwego przepisu z porządku prawnego z moca od dnia jego wejścia w życie, lecz prospektywnie, od dnia ogłoszenia orzeczenia.

$\mathrm{Na}$ innym modelu kształtowania się skutków wyroków negatywnych sądu konstytucyjnego opiera się prawo niemieckie. Za podstawę rozwiązań normatywnych przyjmuje ono teorię nieważności (Nichtigkeitslehre) ( 78 ustawy o FTK ${ }^{11}$ ). W świetle tej teorii przepis niekonstytucyjny jest nieważny od samego początku i nie wchodzi w ogóle do porządku prawnego. Wyrok sądu konstytucyjnego stwierdzający jego niezgodność z konstytucją ma charakter deklaratoryjny.

Jak wspomniano, ,unormowania zawarte w art. 190 ust. 1 i 3 Konstytucji RP wykazuja podobieństwo $\mathrm{z}$ system austriackim"12. Z dniem ogłoszenia negatywnego wyroku TK przepis, co do którego Trybunał orzekł o jego niekonstytucyjności, traci moc obowiązująca ze skutkiem ex nunc ${ }^{13}$. Negatywne orzeczenie TK oznacza wadliwość przepisu, a nie jego nieważność od początku. Nie pozbawia go zatem mocy obowiązującej ze skutkiem wstecznym (ex tunc $)^{14}$, jednakże otwiera drogę do wznowienia postępowania ${ }^{15}$. W polskim systemie prawnym niemożliwe jest zatem traktowanie przepisu niekonsty-

${ }^{10}$ Zob. Z. Czeszejko-Sochacki, Sad konstytucyjny w ustroju konstytucyjnym w Austrii, w: J. Trzciński (red.), Sady konstytucyjne w Europie, t. 1, Warszawa 1996, s. 11.

${ }^{11}$ Ustawa o Federalnym Trybunale Konstytucyjnym, w brzmieniu z 11 sierpnia 1993 r., w tłumaczeniu L. Garlickiego, w: J. Trzciński (red.), op. cit., t. 1, s. 177.

${ }^{12} \mathrm{Ch}$. Grabentwarter, K. Pabel, Skutki orzeczeń o niekonstytucyjności norm wydawanych przez niemiecki Federalny Sad Konstytucyjny oraz austriacki Sad Konstytucyjny, z uwzglednieniem polskiego stanu konstytucyjnego. Opinia prawna sporzadzona na zamówienie Biura TK (dostępna w zbiorach biblioteki TK), s. 34 .

${ }^{13}$ Por. A. Zoll, Skuteczność orzeczeń polskiego Trybunału Konstytucyjnego, w: Ksiega jubileuszowa ku czci profesora Adama Strzembosza, Lublin 2002, s. 255.

14 Tak samo, A. Zoll, Skuteczność orzeczeń polskiego Trybunatu Konstytucyjnego, w: Księa XXV-lecia Trybunatu Konstytucyjnego. Ewolucja funkcji i zadań Trybunatu Konstytucyjnego - zatożenia a ich praktyczna realizacja, Warszawa 2010, s. 62.

${ }^{15}$ Por. K. Działocha, Wykonywanie orzeczeń Trybunatu Konstytucyjnego przez organy powotane do stanowienia prawa, w: Księga XXV-lecia Trybunatu Konstytucyjnego..., s. 70. 
tucyjnego jako niebyłego, a więc takiego, który nie powinien był od początku wywierać żadnych skutków prawnych ${ }^{16}$. Negatywny wyrok TK ma w każdym wypadku charakter konstytutywny, zmienia istniejący stan normatywny i powoduje utratę mocy obowiązującej aktu normatywnego. Tworzy zatem nowa jakość ${ }^{17}$. Konstytutywność wyroku polega także na uchyleniu istniejącego dotąd domniemania, że przepis jest zgodny z Konstytucja ${ }^{18}$. Negatywny wyrok TK jest ponadto zdarzeniem prawnym stanowiącym podstawę do wznowienia postępowania (art. 190 ust. 4 Konstytucji) ${ }^{19}$, które w doktrynie zaliczane jest do pośrednich skutków wyroku ${ }^{20}$. Konstytutywny charakter negatywnych wyroków TK podkreśla zatem także art. 190 ust. 4 Konstytucji RP, określający przesłanki wzruszalności, oraz art. 190 ust. 3 Konstytucji RP, wprowadzający możliwość wskazania przez Trybunał innego niż dzień ogłoszenia wyroku terminu utraty mocy obowiązującej aktu normatywnego ${ }^{21}$.

Trybunał Konstytucyjny nie może retroaktywnie pozbawić mocy zakwestionowanego przepisu ${ }^{22}$. Na skutek negatywnego wyroku TK nie upadaja automatycznie wydane wcześniej orzeczenia sądów, decyzje organów ani czynności prawne, których podstawą był przepis niezgodny z Konstytucja, nie tracą ważności prawa nabyte na podstawie tych przepisów ${ }^{23}$. Negatywny wyrok TK stanowi podstawę konwalidowania indywidualnych aktów stosowania prawa, ale nie przekreśla ich istnienia i nie odmawia im skuteczności prawnej ${ }^{24}$. Nie wiąże się zatem z koniecznością kształtowania na nowo wszystkich stosunków prawnych, ale stwarza szanse ich zrewidowania i pozostawia „nienaruszone" więzi prawne, powstałe na podstawie niekonstytucyjnego przepisu. Regulacja taka zapewnia zatem ,,poszanowanie wartości takich, jak pewność prawa i zaufanie obywateli do państwa, a tym samym poszanowanie trwałości prawomocnych wyroków sądowych i ostatecznych decyzji administracyjnych orzekających o prawach stron" ${ }^{25}$. Retroaktywny skutek rozstrzygnięć mógłby powodować paraliż instytucji państwa prawa ${ }^{26}$.

${ }^{16}$ T. Dębowska-Romanowska, Gtos w dyskusji, w: Ksiega XXV-lecia Trybunatu Konstytucyjnego..., s. 198.

17 Zob. ibidem, s. 199.

${ }_{18}$ Zob. L. Garlicki, Uwagi o charakterze prawnym orzeczeń Trybunatu Konstytucyjnego, w: Studia nad prawem konstytucyjnym (dedykowane Profesorowi Kazimierzowi Dziatosze), Acta Universitatis Wratislaviensis Prawo, t. 157, Wrocław 1997, s. 85-86.

${ }^{19}$ Zob. Z. Czeszejko-Sochacki, Sadownictwo konstytucyjne w Polsce na tle porównawczym, Warszawa 2003 , s. 396.

${ }^{20}$ Zob. L. Garlicki, Uwagi o charakterze prawnym orzeczeń..., s. 86; P. Radziewicz, Przywrócenie mocy obowiazujacej przepisu prawnego jako skutek orzeczenia Trybunatu Konstytucyjnego, „Przegląd Sejmowy" 2005, nr 3, s. 30.

${ }^{21}$ Zob. M. Safjan, Dylematy nie tylko teoretyczne, „Rzeczpospolita” 2011, nr 60.

${ }^{22}$ Zob. Z. Czeszejko-Sochacki, Skutki prawne orzeczenia przez Trybunat Konstytucyjny o niekonstytucyjności aktu normatywnego, „Przegląd Sądowy” 1996, nr 3, s. 23.

${ }^{23}$ Zob. M. Safjan, Skutki prawne orzeczeń Trybunatu Konstytucyjnego, „Państwo i Prawo” 2003, z. 3, s. 13-14; wyrok TK z 27 października 2004 r., SK 1/04, OTK ZU 2004, nr 9 A, poz. 96.

${ }^{24}$ Zob. Zob. L. Garlicki, w: idem (red.), Konstytucja RP. Komentarz, t. 4, Warszawa 2005, uwagi do art. 190 , s. 18 .

${ }^{25}$ Wyrok TK z 8 maja 2000 r., SK 22/99, OTK ZU 2000, nr 4, poz. 107.

${ }^{26}$ Zob. M. Safjan, Skutki prawne orzeczeń Trybunatu Konstytucyjnego, „Państwo i Prawo” 2003, z. 3, s. $13-14$. 
Wynika z tego, że do momentu ogłoszenia wyroku przepis uznany przez TK za niezgodny z Konstytucją istnieje i wywołuje skutki w systemie obowiązującego prawa ${ }^{27}$. W okresie tym korzysta $\mathrm{z}$ domniemania konstytucyjności. Domniemanie to stoi na straży bezpieczeństwa prawnego i poczucia pewności prawnej. Dopiero orzeczenie TK może pozbawić zaskarżony przepis mocy obowiązującej $^{28}$. Nie zmienia to jednak faktu, że do momentu derogowania go obowiązywał on w systemie prawa ${ }^{29}$. Utracić moc obowiązująca mogą tylko te przepisy, które wcześniej cechę taką posiadały ${ }^{30}$. Przepis niekonstytucyjny na mocy decyzji prawodawcy $\mathrm{z}$ chwila jego ustanowienia i wprowadzenia do porządku prawnego staje się częścią obowiązującego systemu prawa, a nie -jak głosi teoria nieważności - w ogóle do porządku prawnego nie wchodzi ${ }^{31}$.

Większość przedstawicieli doktryny jest zgodna co do tego, że wyroki TK stwierdzające niekonstytucyjność zakwestionowanych przepisów mają charakter konstytutywny ze skutkiem ex nunc. Mimo to odnotować także można wypowiedzi o deklaratoryjnym charakterze wyroków polskiego Trybunału Konstytucyjnego wywierających skutek ex tunc ${ }^{32}$ lub też stwierdzających, że wprawdzie maja one charakter konstytutywny, ale mimo to wywieraja skutek ex tunc ${ }^{33}$.

Z kolei odroczenie terminu utraty mocy obowiązującej aktu normatywnego, o którym mowa w art. 190 ust. 3 Konstytucji RP, oznacza, że po ogłoszeniu orzeczenia TK o niekonstytucyjności przepisu może on nadal pozostawać w obrocie prawnym przez określony czas i być regulatorem stosunków społeczno-prawnych określonych w hipotezie normy prawnej oraz źródłem praw i obowiązków wynikających z jej dyspozycji ${ }^{34}$. Przepis ten, choć niekonstytucyjny, jest nadal - na podstawie art. 190 ust. 3 Konstytucji RP - częścią systemu prawa ${ }^{35}$.

Kolejnym przepisem, który należy uwzględnić $\mathrm{w}$ analizie istoty nadpłaty powstałej w wyniku orzeczenia TK, jest art. 190 ust. 4 Konstytucji RP. Wznowienie postępowania na podstawie tego przepisu przysługuje w sprawach zakończonych prawomocnym orzeczeniem sądowym, ostateczna decyzja administracyjną lub rozstrzygnięciem $\mathrm{w}$ innych sprawach, jeżeli podstawą ich wydania był przepis, którego niekonstytucyjność została stwierdzona w orzeczeniu Trybunału Konstytucyjnego. Wznowienie w takiej sytuacji jest możliwe na zasadach i w trybie określonych $\mathrm{w}$ przepisach właściwych dla danego postępowania. Artykuł 190 ust. 4 Konstytucji RP, przewidujący możliwość

${ }^{27}$ L. Garlicki, Uwagi o charakterze prawnym orzeczeń..., s. 86.

${ }^{28}$ Por. Z. Czeszejko-Sochacki, Sadownictwo konstytucyjne w Polsce..., s. 392.

${ }^{29}$ Por. L. Garlicki, Uwagi o charakterze prawnym orzeczeń..., s. 86.

${ }^{30}$ Por. postanowienie TK z 21 marca 2000 r., K 4/99, OTK ZU 2000, nr 2, poz. 65.

${ }^{31}$ M. Florczak-Wątor, Orzeczenia Trybunat Konstytucyjnego i ich skutki prawne, Poznań 2006, s. 70.

${ }^{32}$ Zob. B. Wierzbowski, Skutki wyroków Trybunatu Konstytucyjnego dotyczacych prawa podatkowego, w: Ksiega pamiatkowa ku czci docenta Eligiusza Drgasa. Studia z zakresu Ordynacji podatkowej, Torun 1998, s. 201 i 204.

${ }^{33}$ Zob. K. Pietrzykowski, Problem skuteczności ex tunc albo ex nunc orzeczeń Trybunatu Konstytucyjnego $w$ orzecznictwie Sadu Najwyższego, w: Ksiega jubileuszowa ku czci profesora Adama Strzembosza, s. 290.

${ }^{34}$ Zob. A. Józefowicz, Ex tunc czy ex nunc, „Prawo i Życie” 2001, nr 2, s. 76.

${ }^{35}$ Por. np. wyrok TK z 27 kwietnia 2005 r., P 1/05, OTK ZU 2005, nr 4/A, poz. 42. 
wzruszenia prawomocnych orzeczeń sądowych, ostatecznych decyzji administracyjnych oraz bliżej niesprecyzowanych rozstrzygnięć w innych sprawach ${ }^{36}$, przyznaje jednocześnie jednostce prawo podmiotowe ${ }^{37}$ do rozstrzygnięcia sprawy $\mathrm{w}$ następstwie utraty mocy obowiązującej przez zdyskwalifikowana normę prawną. Przepis ten, odsyłając do ustaw zwykłych, nakazuje regulację trybu tzw. sanacji konstytucyjności, a tym samym determinuje cel „,wznowienia" ${ }^{38}$. Nie oznacza to, że art. 190 ust. 4 Konstytucji RP modyfikuje charakter wyroków Trybunału Konstytucyjnego, nadając im skuteczność ex tunc, tzn. znosi znaczenie art. 190 ust. 3 Konstytucji RP. Przepisu tego nie należy bowiem traktować jako wyjątku od art. 190 ust. 3 Konstytucji RP, lecz jako stwarzający możliwość konwalidowania indywidualnych aktów stosowania prawa na zasadach i w trybie określonym przez ustawy właściwe dla danych gałęzi prawa. Wprowadzając możliwość sanacji konstytucyjności, ustrojodawca pozostawił swobodę wyboru zachowania i inicjatywę w tym względzie podmiotom zainteresowanym, bez podważania ważności i skuteczności pozostałych - ukształtowanych pod rządami przepisu uznanego za niekonstytucyjny stosunków prawnych. Uprawnienie z art. 190 ust. 4 Konstytucji RP jest jednym z następstw, jakie Konstytucja wiąże ze stwierdzeniem niekonstytucyjności przepisu, ale nie należy traktować go jako wpływający na przyjęty model skutków wyroków TK. Z woli podmiotu uprawnionego w tym zakresie chcącego skorzystać $\mathrm{z}$ ponownego rozpatrzenia sprawy $\mathrm{w}$ stanie prawnym, ukształtowanym wyrokiem TK, nie można wywodzić konkluzji o modyfikowaniu charakteru i skutków wyroków TK określonych w art. 190 ust. 3 Konstytucji RP. Nie można zatem uznać, że w świetle art. 190 ust. 4 Konstytucji RP wyroki te maja charakter deklaratoryjny ze skutkiem ex tunc. Konstytucja w art. 190 ust. 3 chroni zatem trwałość ostatecznych rozstrzygnięć i ukształtowanych stosunków prawnych, lecz jednocześnie nie wyłącza możliwości uzyskania ponownego rozstrzygnięcia indywidualnej sprawy w warunkach ukształtowanych wejściem w życie wyroku TK, na zasadach i w trybie określonym w art. 190 ust. 4.

\section{ZNACZENIE I FUNKCJA ART. 74 O.P. W ŚWIETLE ART. 190 UST. 4 KONSTYTUCJI}

Ustawami zwykłymi, do których odsyła art. 190 ust. 4 Konstytucji RP, w sprawach podatkowych sa Ordynacja podatkowa i Prawo o postępowaniu przed sądami administracyjnymi ${ }^{39}$. Zarówno $\mathrm{z}$ art. $240 \S 1$ pkt 8 o.p., jak i $\mathrm{z}$ art. $272 \S 1$ p.p.s.a. wynika, że przesłanką wznowienia postępowania w sprawie zakończonej ostateczną decyzją lub prawomocnym orzeczeniem jest

${ }^{36}$ Por. J. Repel, Skutki prawne orzeczenia Trybunatu Konstytucyjnego $w$ sprawie skargi konstytucyjnej, w: J. Trzciński (red.), Skarga konstytucyjna, Warszawa 2000, s. 216.

${ }^{37}$ Wyrok TK z 27 października 2004 r., SK 1/04, OTK ZU 2004, nr 9/A, poz. 96.

38 Por. ibidem.

${ }^{39}$ Ustawa z 30 sierpnia 2002 r. - Prawo o postępowaniu przed sądami administracyjnymi, Dz. U. Nr 153, poz. 1270 ze zm. (dalej jako: p.p.s.a.). 
stwierdzenie niezgodności z Konstytucją, ustawą lub ratyfikowaną umową międzynarodową przepisu, który stanowił podstawę wydania takich orzeczeń.

Zakres podmiotowy obu wskazanych podstaw wznowienia postępowania ograniczony jest tylko do tych podatników, którym określono lub ustalono zobowiązanie podatkowe w decyzji ostatecznej lub prawomocnym wyroku, wydanych na podstawie przepisu zakwestionowanego przez TK, a więc do sfery stosowania prawa. Oznacza to, że podatnicy, którzy uiścili podatek na podstawie przepisu uznanego za niezgodny z Konstytucją przez TK, określając jego wysokość w zeznaniu, deklaracji (czy też bez ich składania, jeżeli przepisy prawa podatkowego nie przewidują takiego obowiązku), nie moga dochodzić zwrotu podatku w trybie wznowienia postępowania.

Podatnikami dysponującymi decyzja ostateczną lub prawomocnym wyrokiem są tylko podatnicy, w stosunku do których organ wszczął postępowanie podatkowe i ujawnił zaległość; podatnicy, którzy mając wątpliwości co do znaczenia przepisu i wysokości kwoty podatku z niego wynikającej, zapłacili świadczenie w kwocie wyższej, a następnie zwrócili się o stwierdzenie nadpłaty, a nawet doprowadzili do wydania wyroku w tej sprawie przez TK; oraz podatnicy, których zobowiązanie podatkowe powstaje na podstawie decyzji ustalającej wysokość zobowiązania podatkowego (art. $21 \S 1$ pkt 2 o.p.). W pierwszej grupie podatników znajdują się zarówno ci, którzy ujawniają swoje dochody (obrót), lecz popełnili błąd, określając zobowiązanie podatkowe, jak również ci, którzy uchylaja się od płacenia podatków. Wśród podatników, których zobowiązania powstają z mocy prawa, tylko wymienionym wyżej przysługiwałoby uprawnienie do żądania wznowienia postępowania, a w konsekwencji - zwrotu zapłaconego podatku. Brak natomiast możliwości uzyskania zwrotu podatku przez podatników, którzy płacą zobowiązania lojalnie, wywiązując się wobec państwa $\mathrm{z}$ nałożonych na nich obowiązków, wzbudzałby w nich poczucie niesprawiedliwości i nagradzania postaw postępowania wbrew konstytucyjnym obowiązkom. Sytuacja taka byłaby zatem sprzeczna z zasada sprawiedliwości społecznej, wynikającej z art. 2 Konstytucji RP. Powodowałaby również nierówne traktowanie podatników, w szczególności w stosunku do tych, którzy uchylają się od płacenia podatków.

Trybunał Konstytucyjny w swoim orzecznictwie wielokrotnie zwracał uwagę, że pojęcie ,,wznowienia postępowania”, o którym mowa w art. 190 ust. 4 Konstytucji RP, ,nie należy rozumieć w sensie technicznym, w jakim posługują się nim przepisy proceduralne (wznowienie sensu stricto)" ${ }^{40}$. Autonomiczny charakter pojęć użytych w art. 190 ust. 4 Konstytucji RP powoduje, że należy odczytywać go jako nakaz szczególnego uregulowania w przepisach właściwych dla danego postępowania zasad i trybu tzw. sanacji konstytucyjności orzeczeń $\mathrm{w}$ sprawach indywidualnych ${ }^{41}$. Chodzi zatem o wszelkie środki prawne postawione stronom i sądom do dyspozycji, dzięki którym można osiągnąć efekt $\mathrm{w}$ postaci ponownego rozstrzygnięcia sprawy, według stanu prawnego po wyeliminowaniu niekonstytucyjnych przepisów" ${ }^{42}$. Wznowienie to ma zatem

\footnotetext{
${ }^{40}$ Wyrok TK z 7 września 2006 r., SK 60/05, OTK ZU 2006, nr 8/A, poz. 101.

${ }^{41}$ Wyrok TK z 28 listopada 2006 r., SK 19/05, OTK ZU 2006, nr 10/A, poz. 154.

${ }^{42}$ Wyrok TK z 7 września 2006 r., SK 60/05, OTK ZU 2006, nr 8/A, poz. 101.
} 
znacznie szerszy sens ${ }^{43}$. Wynika $\mathrm{z}$ niego konstytucyjne prawo podmiotowe uruchomienia procedur zmierzających do wydania nowego rozstrzygnięcia, opartego na stanie prawnym powstałym po orzeczeniu Trybunału Konstytucyjnego" ${ }^{44}$. Artykuł 190 ust. 4 Konstytucji RP nie może być zatem traktowany jako „dyrektywa programowa”, lecz jako „obowiązek efektywnej implementacji” ${ }^{45}$.

Jednakże skutki wdrożenia postanowień art. 190 ust. 4 Konstytucji RP na grunt poszczególnych gałęzi prawa pod względem adekwatności doboru przesłanek jego zastosowania i możliwość skorzystania z sanacji konstytucyjności w sferze oddziaływania niekonstytucyjnego przepisu nie zostały jeszcze dostatecznie zbadane i określone. Inaczej będą kształtowały się konsekwencje przepisów realizujących postanowienia art. 190 ust. 4 Konstytucji RP w prawie karnym, cywilnym, administracyjnym i podatkowym. Artykuł 190 ust. 4 Konstytucji RP, przewidując jako przesłankę wznowienia postępowania wydanie prawomocnego orzeczenia sądowego, ostatecznej decyzji administracyjnej lub rozstrzygnięcia w innych sprawach, odnosi się do sfery stosowania prawa.

Gdyby jednak przyjąć, że funkcje art. 190 ust. 4 Konstytucji RP w zakresie prawa podatkowego realizowane sa w ustawach zwykłych tylko na podstawie art. $240 \S 1$ pkt 8 o.p. i art. $272 \S 1$ p.p.s.a., większość podatników pozbawiona byłaby możliwości skorzystania $\mathrm{z}$ prawa ,sanacji konstytucyjności”. Poza zakresem jego działania znalazłyby się bowiem wszystkie te wypadki, w których skutki obowiązywania niekonstytucyjnych przepisów dotykają sfery przestrzegania prawa.

Sposób ukształtowania systemu powstawania i wygasania zobowiązań $\mathrm{w}$ prawie podatkowym, w którym w przeważającej mierze zobowiązania powstają z mocy prawa, powoduje, że $\mathrm{w}$ większości wypadków podatnicy nie dysponuja ostatecznym lub prawomocnym orzeczeniem. W tych wszystkich sytuacjach, w których zobowiązania podatkowe powstaja z mocy prawa, podatnicy zobowiązani są do samoobliczenia i zapłaty obliczonej w ten sposób kwoty podatku bez wezwania organu, w określonym przez ustawę terminie.

Biorąc natomiast pod uwagę powszechność, stałość i powtarzalności obowiązku ponoszenia ciężarów publicznych, jakimi są podatki, podatnicy byliby zatem pozbawieni możliwości sanacji konstytucyjności, w stopniu nieporównywalnym do sytuacji podmiotów innych gałęzi prawa.

Stąd też autonomiczny charakter pojęć użytych w art. 190 ust. 4 Konstytucji RP, a także wywodzone $\mathrm{z}$ niego prawo podmiotowe należy rozumieć jako obowiązek ustawodawcy do wprowadzenia zróżnicowanych środków, realizujących prawo podmiotowe podatników, o którym mowa w tym przepisie. Sposób ich ukształtowania powinien odpowiadać kryteriom powstawania zobowiązań i sposobom oraz formom ich wymierzania, tak aby wszyscy podatnicy, którzy zapłacili podatek na podstawie przepisu niezgodnego z Konstytucja, mieli zapewnioną możliwość skorzystania z prawa do ,sanacji konstytucyjności”.

\footnotetext{
${ }^{43}$ Por. wyrok TK z 2 marca 2004 r., SK 53/03, OTK ZU 2004, nr 3/A, poz. 16.

${ }^{44}$ Wyrok TK z 27 października 2004 r., SK 1/04, OTK ZU 2004, nr 9/A, poz. 96.

${ }^{45}$ Wyrok TK z 7 września 2006 r., SK 60/05, OTK ZU 2006, nr 8/A, poz. 101.
} 
Ze względu na powszechność, stałość, powtarzalność obowiązku podatkowego, a także obowiązek samoobliczenia, które czynią z podatków obowiązek obywatelski nieporównywalny $\mathrm{z}$ innymi obowiązkami względem państwa, konstytucyjne prawo podmiotowe, wynikające z art. 190 ust. 4 Konstytucji RP, nie może być ograniczone tylko do tych podatników, których wysokość zobowiązania została określona lub ustalona $\mathrm{w}$ orzeczeniach posiadających przymiot ostateczności (prawomocności).

Z innych zatem środków korzystać będą podatnicy dysponujący ostatecznym lub prawomocnym orzeczeniem, a $\mathrm{z}$ innych ci, którzy uiścili podatek $\mathrm{w}$ wysokości wynikającej $\mathrm{z}$ wymiaru ujawnionego $\mathrm{w}$ deklaracji lub zeznaniu podatkowym. W tym ostatnim wypadku nie wchodzi w grę możliwość uruchomienia środków procesowych, które doprowadzą do uzyskania przez nich nowego rozstrzygnięcia, ponieważ rozstrzygnięcie takie w ogóle nie miało miejsca.

Za środek taki dla podatników, którzy uiścili podatek w wysokości wykazanej w zeznaniu lub deklaracji, uznać należy roszczenie uregulowane w art. 74 o.p. Przepis ten obejmuje swym zakresem wszystkie te wypadki, w których zobowiązania powstaja z mocy prawa. Stwarza tym samym możliwość ,,sanacji konstytucyjności” także dla tych podatników, którzy nie dysponuja ostatecznym lub prawomocnym rozstrzygnięciem.

W orzecznictwie sądów administracyjnych wyrażany jest pogląd, że art. 74 o.p. jest przepisem określającym zasady i tryb postępowania, o których mowa w art. 190 ust. 4 Konstytucji $\mathrm{RP}^{46}$. Sądy te, choć słusznie zauważaja związek art. 74 o.p. z art. 190 ust. 4 Konstytucji RP, to jednak niezupełnie prawidłowo odczytuja wzajemne relacje tych przepisów. Artykuł 74 o.p. nie dotyczy wprost wznowienia postępowania, w sensie technicznym, ani nie odnosi się do orzeczeń ostatecznych, ani prawomocnych. Dlatego też związek ten należy rozpatrywać na płaszczyźnie pełnionych funkcji. Artykuł 74 o.p. stanowi realizacje prawa podmiotowego wynikającego z art. 190 ust. 4 Konstytucji RP na gruncie Ordynacji podatkowej - adekwatny do sposobu i formy wymierzania zobowiązań podatkowych (powstających $\mathrm{z}$ mocy prawa). Wąsko rozumiany art. 190 ust. 4 Konstytucji RP w prawie podatkowym nie mógłby w pełni spełnić swojej zasadniczej funkcji, jaką przypisał mu ustrojodawca, a jego rola gwarancyjna byłaby znacznie ograniczona i często prowadziłaby do nagradzania tych, którzy podatków nie płacą i w stosunku do których toczyło się postępowanie zakończone ostateczną decyzją lub wyrokiem sądu.

Realizacja przez ustawodawcę konstytucyjnego prawa do tzw. sanacji konstytucyjności, wynikającego $\mathrm{z}$ art. 190 ust. 4 Konstytucji RP, w prawie podatkowym wymaga wprowadzenia odpowiednich środków nie tylko w sferze stosowania prawa, lecz także w sferze jego przestrzegania.

Artykuł 74 o.p., określając odrębny tryb zwrotu „nadpłaty powstałej w wyniku orzeczenia TK", pod względem pełnionych funkcji stanowi realizację powyższego, konstytucyjnego obowiązku ustawodawcy. Zapewnia środki gwarantujące tzw. sanację konstytucyjności, której skutkiem w prawie podatkowym jest obowiązek zwrotu podatku pobranego na podstawie przepisu, którego zgodność z Konstytucją zakwestionował Trybunał.

${ }^{46}$ Zob. np. wyrok NSA z 7 kwietnia 2004 r., FSK 16/04, CBOSA. 
Warto także zwrócić uwagę, że w wypadku ,nadpłaty powstałej w wyniku orzeczenia TK" podatnicy składają wniosek o zwrot nadpłaty, a nie jak w art. 75 $\S 1$ o.p. wniosek o stwierdzenie nadpłaty. Sanowanie sytuacji prawnej podatników, o której mowa w art. 190 ust. 4 Konstytucji RP, w nowym stanie prawnym, ukształtowanym wyrokiem Trybunału, w prawie podatkowym, wymaga uwzględnienia faktu usunięcia z porządku prawnego przepisu, który był podstawą uiszczenia podatku. W konsekwencji uiszczenie podatku na podstawie przepisu uznanego przez TK za niezgodny z Konstytucją skutkować będzie powstaniem nadpłaty w wysokości równej kwocie uiszczonego podatku. Jej określenie nie wymaga - jak w wypadku nadpłaty z art. 72 o.p. - badania, czy powstało zobowiązanie podatkowe i jaka jest jego wysokość. Ustalenie, że podstawą zapłaty podatku był przepis uznany następnie za niezgodny z Konstytucja, przesądza, niejako automatycznie, o powstaniu ,nadpłaty” i jej wysokości. Inną natomiast kwestią, która wykracza poza ramy tego opracowania, jest to, czy i komu należy się zwrot nadpłaty. W zakresie podatków bezpośrednich Ordynacja podatkowa pozwala na zwrot nadpłaty w całości podatnikowi. Natomiast zwrot nadpłat w podatkach pośrednich budzi wiele kontrowersji. Dyskusyjne jest bowiem to, czy podatnikowi przysługuje zwrot, nawet gdy nie poniósł ciężaru tego podatku. To natomiast przenosi polemikę na płaszczyznę rozważań o zubożeniu jako przesłance powstania nadpłaty. W tym miejscu jedynie pragnę zaznaczyć, że - w mojej ocenie - tezy stawiane w doktrynie i orzecznictwie o konieczności zwrotu całości nadpłaty podatnikowi formalnemu bez względu na to, czy poniósł on ciężar podatku, czy też nie, nie uwzględniaja konstytucyjnej zasady ochrony prawa własności, stanowiącej podstawowe uzasadnienie uregulowania nadpłaty w Ordynacji podatkowej. Jednakże konsekwentne zrealizowanie tej zasady wymaga interwencji ustawodawcy i wprowadzenia odpowiednich regulacji gwarantujących ochronę prawa własności.

\section{WNIOSKI}

$\mathrm{Z}$ ustalenia, że art. 74 o.p. stanowi realizację funkcji art. 190 ust. 4 Konstytucji RP w prawie podatkowym, wynika, iż przepis ten nie tylko reguluje odrębny tryb zwrotu podatku - dostosowany do zasad powstawania i wymiaru zobowiązań podatkowych, lecz także zawiera treści materialnoprawne, pozwalające na określenie istoty i charakteru „,nadpłaty powstałej w wyniku orzeczenia Trybunału Konstytucyjnego". Uwzględnienie skutków wyroków Trybunału pozwala na dekodowanie $\mathrm{z}$ tego przepisu normy definiującej to pojęcie.

„Nadpłata” powstała na skutek stwierdzenia niezgodności zaskarżonego przepisu z Konstytucją wykazuje cechy odrębne od nadpłaty, o której mowa w art. $72 \S 1$ pkt 1 o.p. W odróżnieniu od tej ostatniej przesłanką powstania „,nadpłaty” określonej w art. 74 o.p. nie jest brak podstawy prawnej do świadczenia uiszczonego jako podatek $\mathrm{w}$ momencie jego zapłaty ${ }^{47}$. Wręcz

${ }^{47}$ Zob. A. Szymczak, Determinanty ksztattowania pojęcia nadptaty podatkowej, „,Kwartalnik Prawa Podatkowego" 2011, nr 2, s. 41-42. 
przeciwnie. $\mathrm{W}$ chwili uiszczenia podatku podstawa prawna obowiazku jego zapłaty istniała i korzystała $\mathrm{z}$ domniemania konstytucyjności. Podstawa taka nie odpada z mocą wsteczną po ogłoszeniu wyroku Trybunału. Jak już wskazane zostało wyżej, wyroki TK maja charakter konstytutywny i działaja na przyszłość. Derogowanie przepisu z systemu obowiązującego prawa następuje od dnia ogłoszenia wyroku, co oznacza, że przepis choć niekonstytucyjny, obowiązywał i wywierał określone w nim skutki prawne. Możliwość konwalidacji skutków prawnych stosunków prawnopodatkowych w świetle art. 190 ust. 4 Konstytucji RP nie oznacza natomiast modyfikacji charakteru wyroków, lecz pozwala na ponowne zbadanie sprawy w nowym stanie prawnym tym, którzy zwrócą się z takim żądaniem.

Jak z powyższego wynika, uiszczone świadczenie było podatkiem należnym w chwili jego zapłaty. Z wyrokiem TK nie wiąże się unicestwienie skutków prawnych zaistniałych przed stwierdzeniem niezgodności zaskarżonego przepisu z Konstytucją. Zebrane na podstawie takiego przepisu podatki były planowane jako dochód budżetowy państwa lub jednostki samorządu terytorialnego, a zwrot zawsze będzie się wiązał z nieprzewidzianymi skutkami finansowymi. Nie ma tu miejsca bezpodstawne wzbogacenie państwa lub jednostki samorządu terytorialnego.

Jest to zatem zupełnie inna konstrukcja niż ta, którą posługuje się ustawodawca w art. 72 § 1 o.p., w którym wspólną przesłanka powstania nadpłaty jest uiszczenie świadczenia jako podatek lub jako inne świadczenie, określone w art. $72 \S 1$ pkt 3 i 4 o.p., bez podstawy prawnej do ich poboru ${ }^{48}$.

Rekonstrukcja pojęcia ,nadpłata powstała w wyniku orzeczenia TK”, pozwala na stwierdzenie, że jest ona $\mathrm{w}$ istocie zwrotem podatku. Mimo że nie jest nienależnym świadczeniem, lecz $\mathrm{w}$ chwili zapłaty prawidłowo uiszczonym podatkiem, to Konstytucja łącząc $\mathrm{z}$ negatywnym wyrokiem TK obowiązek tzw. sanacji konstytucyjności, nakazuje zwrot takiego podatku. Został on bowiem pobrany bez odpowiedniej ku temu podstawy prawnej.

Uzasadnienie przyjęcia takiej regulacji jest inne niż w wypadku nadpłaty z art. 72 o.p. Nie wynika ono stąd, że państwo ma prawo do poboru tylko takich podatków, które maja podstawę w ustawie (art. $217 \mathrm{w}$ związku z art. 84 Konstytucji RP), lecz stąd, że demokratyczne państwo prawne nie może czerpać korzyści z naruszania przepisów Konstytucji dotyczących nakładania podatków.

Gwarancje konstytucyjne zwrotu podatków w takiej sytuacji stanowią art. 2 w związku z art. 217 Konstytucji RP. Stanowienie podatków z pogwałceniem zasad konstytucyjnych uznaje się za tak doniosłe i obarczone tak ciężką wada i dezaprobatą społeczna, że reakcja na jej wystapienie jest obowiązek zwrotu podatków pobranych na podstawie takiego przepisu.

Z przedstawionej analizy wynika także, że obowiązek zwrotu podatku, o którym mowa w art. 74 o.p., ma charakter gwarancyjno-prewencyjny. Państwo musi się liczyć z tym, że skutkiem stanowienia podatków wbrew wymaganiom konstytucyjnym będzie obowiązek ich zwrotu, nawet jeżeli pociaga to za sobą powstanie nieprzewidzianych skutków finansowych.

${ }^{48}$ Ibidem, s. 41. 
Na inne znaczenie pojęcia ,nadpłata powstała w wyniku wyroku Trybunału Konstytucyjnego" wskazuje T. Dębowska-Romanowska. Zdaniem autorki nadpłata ta jest ,,sui generis »zadośćuczynieniem《 za nadużycie władzy przez ustawodawcę [...]" ${ }^{\prime 9}$. Wprawdzie nie rozwinęła ona tej tezy, ale z poczynionych wywodów wynika, że traktuje je jako nowe, odrębne roszczenie powstałe na skutek stwierdzenia niekonstytucyjności przepisu przez TK.

Podsumowując wyniki analizy treści art. 74 o.p. w związku z art. 190 ust. 4 Konstytucji RP, należy podkreślić, że pojęcie „,nadpłata powstała w wyniku orzeczenia TK" różni się istotnie od nadpłaty, o której mowa w art. $72 \S 1$ o.p. Inne są nie tylko stan faktyczny związany z powstaniem tej „nadpłaty” i tryb jej zwrotu, lecz także treść materialnoprawna samego pojęcia. Nie jest świadczeniem uiszczonym bez podstawy prawnej, lecz zwrotem podatku uiszczonego na podstawie przepisu uznanego następnie przez Trybunał za niezgodny $\mathrm{z}$ Konstytucją. Nie można zatem uznać, że mieści się ona $\mathrm{w}$ zakresie pojęcia nadpłaconego lub nienależnie uiszczonego podatku, o których mowa w art. 72 $\S 1$ pkt 1 o.p. Stanowi ona źródło nowego roszczenia, różniące się pod względem istoty i charakteru od nadpłaty, o której mowa w tym ostatnim przepisie.

Jej odrębne uregulowanie znajduje uzasadnienie w odmienności przesłanek powstania nadpłaty i związanych z nią skutków prawnych. Konsekwencja uznania, że roszczenie $\mathrm{z}$ art. 74 o.p. stanowi zwrot podatku jest przyjęcie, że momentem jego powstania jest dzień ogłoszenia wyroku TK lub odpowiednio termin późniejszy, jeżeli Trybunał odroczy wejście wyroku w życie. Odrębność uregulowania dotyczy także kwestii przedawnienia się roszczenia o zwrot nadpłaty. Ponieważ w art. 74 o.p. mowa jest o ,wniosku o zwrot nadpłaty”, a przepisy dotyczące przedawnienia odnosza się tylko do „wniosku o stwierdzenie nadpłaty", w mojej ocenie, nie podlegaja one obecnie przedawnieniu.

mgr Aneta Szymczak

Uniwersytet Łódzki

aszymczak@wpia.uni.lodz.pl

\title{
OVERPAYMENT AS A RESULT OF A JUDGMENT OF THE CONSTITUTIONAL TRIBUNAL
}

\author{
Summary
}

The paper concerns the concept of overpayment made as a result of a judgment delivered by the Constitutional Tribunal in reference to Article 72 and 74 of the Tax Ordinance Act. Although the doctrine and the judicature of administrative courts view overpayment under Article 74 as stemming from Article 72 of the Tax Ordinance Act, there are certain distinct features of the two. Taking into consideration the potential effects of the judgment of the Polish Constitutional Tribunal, a tax paid when the legal footing of this tax was in existence is considered as being due at the date of payment. A distinction is made between overpayment stemming from article 74 and overpayment stemming from article 72. The latter features a lack of legal footing for tax payment. This distinction also has further implications and consequences.

${ }^{49}$ T. Dębowska-Romanowska, Prawo finansowe, część konstytucyjna wraz z częścia ogólna, Warszawa 2010, s. 159 . 
Copyright of Journal of Law, Economics and Sociology is the property of Faculty of Law and Administration of Adam Mickiewicz University in Poznan and its content may not be copied or emailed to multiple sites or posted to a listserv without the copyright holder's express written permission. However, users may print, download, or email articles for individual use.

Właścicielem praw autorskich do „Ruchu Prawniczego, Ekonomicznego i Socjologicznego” jest Wydział Prawa i Administracji Uniwersytetu im. Adama Mickiewicza w Poznaniu. Zawartość czasopisma nie może być kopiowana, przesyłana do innych stron internetowych bądź zamieszczana na blogach bez pisemnej zgody wydawcy. Niemniej artykuły można drukować, kopiować lub przesyłać w formie elektronicznej na własny użytek. 